\title{
Kajian Kompetensi Ahli K3 terhadap Kinerja SMK3 pada PLTGU POMU Priuk
}

\author{
Refdi Madefri $^{(1)}$ dan Tatan Sukwika ${ }^{(2, a)^{*}}$ \\ ${ }^{(1)}$ Program Studi Magister Manajemen, Universitas Sahid, Jakarta, Indonesia \\ ${ }^{(2)}$ Program Studi Teknik Lingkungan, Universitas Sahid, Jakarta, Indonesia \\ Email: ${ }^{\left(a^{*}\right)}$ tatan.swk@gmail.com
}

Diterima (1 Oktober 2021), Direvisi (29 Desember 2021)

\begin{abstract}
The results of internal and or external audit assessment on OHS management system (SMK3) performance tend to be volatile in POMU Priuk power plant companies throughout 2015-2019. This research aims to analyze the competence of OHS experts to SMK3 performance. The samples used in this study amounted to 135 people, the data collected in the form of perceptions of OHS experts on competencies (attitudes, knowledge, abilities) and performance smk3. The data analysis method used classical assumption test, regression, determination and hypothesis. The results of the study are known that simultaneously that attitudes, knowledge and abilities are proven to affect the performance of SMK3. The conclusion is that the attitude carried out by OHS experts is not proven to affect performance, on the contrary, the knowledge and capabilities of OHS experts are proven to be able to affect performance. The managerial implications of the companies need to strive to improve competence through education and training through training on the job training or fieldwork practices.
\end{abstract}

Keywords: OHS expert competence, SMK3 performance, PLTGU-Priuk

Abstrak. Hasil penilaian audit internal dan atau ekternal pada kinerja system manajemen K3 (SMK3) cenderung fluktuatif di perusahaan PLTGU POMU Priuk sepanjang tahun 2015-2019. Penelitian ini bertujuan untuk menganalisa kompetensi ahli K3 terhadap kinerja SMK3. Sampel yang digunakan pada penelitian ini berjumlah 135 orang, data yang dikumpulkan berupa persepsi terhadap ahli K3 mengenai kompetensi (sikap, pengetahuan, kemampuan) dan kinerja SMK3. Metode analisis data digunakan uji asumsi klasik, regresi, determinasi dan hipotesis. Hasil penelitian diketahui bahwa secara simultan bahwa sikap, pengetahuan dan kemampuan terbukti mempengaruhi kinerja SMK3. Kesimpulannya yaitu sikap yang dijalankan oleh Ahli K3 tidak terbukti mampu mempengaruhi kinerja, sebaliknya, pengetahuan dan kemampuan yang dimiliki Ahli K3 terbukti mampu mempengaruhi kinerja. Implikasi manajerialnya perusahaan perlu berupaya meningkatkan kompetensi dengan melalui pendidikan dan pelatihan melalui pelatihan on job training atau praktek kerja lapangan.

Kata kunci: Kompetensi ahli K3, Kinerja SMK3, PLTGU-Priuk

\section{PENDAHULUAN}

Manajemen, Ahli K3 (keselamatan kesehatan kerja) dan tenaga kerja berupaya menurunkan risiko dan menghilangkan kecelakaan kerja. Ahli K3 sangat diperlukan diperusahaan untuk terlaksananya $\mathrm{K} 3$ yang baik dan terhindar dari potensi berbagai bahaya. Pada umumnya dalam sebuah penerapan sistem keamanan (safety) melibatkan pemerintah, perusahaan atau penyedia jasa, dan tenaga kerja itu sendiri. Peran Pemerintah dalam hal keselamatan (safety) sebagai regulator terkait K3 dituangkan dalam UU No. 13 Tahun 2003 dalam Pasal 87 yang 
menyatakan bahwa ketentuan mengenai penerapan Sistem Manajemen Keselamatan dan Kesehatan Kerja diatur dengan Peraturan Pemerintah (PP) yang dituangkan dalam PP No. 50 Tahun 2012. Peran Pengusaha dalam penerapan sebuah sistem keselamatan (safety) adalah pengusaha wajib menerapkan sistem keamanan itu sendiri sesuai regulasi diatas.Selanjutnya pada tingkat tenaga kerja yaitu menggunakan Alat Pelindung Diri (APD) yang diwajibkan sebagai syarat Keselamatan dan Kesehatan Kerja. Oleh karena itu, peran K3 menjadi strategis sebagai atribut penilaian. Penelitian Noviastuti, et al. [1] menyebutkan untuk mencegah kecelakaan kerja dengan melakukan penetapan kebijakan dan peraturan perundang-undangan yang berlaku.

Kompetensi sangat diperlukan, terkhusus untuk Ahli K3 baik berupa tingkat utama, madya dan muda. Penyusunan standar kompetensi K3 ini bertujuan untuk meningkatkan kualitas dan kompetensi SDM K3 [2].

Dalam menunjang kompetensi, maka ada tiga variabel yang dapat menyempurnakan kompetensi yaitu pengetahuan (knowledge) dan kemampuan (skill), dan sikap (attitude) artinya kompetensi itu baik, maka kinerja di perusahaan juga akan baik dan berhasil. Adapun tolak ukur suatu perusahaan akan baik dan berhasil, manakala hasil kinerja perusahaan juga sesuai dengan PP No.50 Tahun 2012. Pada tahun 2008 World Health Organization menyusun pedoman "a guide to developing knowledge, attitude and practice surveys" dimana knowledge, skill, dan attitude (KSA) menjadi indicator pengukuran kompetensi untuk membantu mengumpulkan data yang kemudian digunakan untuk perencanaan, perbaikan, dan evaluasi kinerja. Pengukuran kompetensi melalui KSA juga berguna untuk mengetahui atau mengeksplorasi perubahan pada pengetahuan, sikap maupun tindakan pada komunitas atau para pekerja. Noviastuti, et al. [1] menjelaskan pengidentifikasian kompetensi kerja diperlukan pada setiap tingkatan manajemen perusahaan diantaranya melalui menyelenggarakan pendidikan dan pelatihan yang dibutuhkan.

Kompetensi yang dimiliki oleh Ahli K3 sudah baik, tetapi pada pelaksanaannya tidak sesuai tidak semua kinerja dilakukan oleh Ahli K3. Dengan demikian kompetensi yang diharapkan belum mampu meningkatkan kinerja seluruh unit dalam perusahaan Pembangkit Listrik Tenaga Gas dan Uap (PLTGU) POMU Priuk. Penelitian Ardi dan Hariyono [3] bahwa kompetensi yang baik yaitu dengan adanya seorang Ahli K3, dan ini terlihat dari adanya program pelatihan $\mathrm{K} 3$, penggunaan $\mathrm{APD}$ dan lingkungan kerja yang merupakan faktor dalam mencapai budaya dan ramburambu K3 .

Setiap perusahaan berupaya mengurangi kejadian kecelakaan kerja pada kegiatan operasional perusahasannya melalui penerapan SMK3 (sistem manajemen keselamatan kesehatan kerja). Ironisnya walaupun perusahaan sudah menerapkan SMK3 sesuai dengan prosedur, namun kinerjanya masih fluktuatif dari hasil perolehan penilaian kinerja di perusahaan. Kondisi serupa tersebut ditemukan juga oleh Noviastuti, et al. [1] bahwa walaupun perusahaan telah melaksanaan pelatihan K3 disertai adanya kebijakan dari perusahaan namun upaya pencegahan kecelakaan kerja belum dapat optimal. Salah satunya seperti terjadi pada perusahaan PLTGU POMU Priuk. Berikut daftar penilaian hasil audit SMK3 di Perusahaan PLTGU POMU Priuk tahun 2015-2019 seperti pada Tabel 1. 
Tabel 1. Penilaian Hasil Audit SMK3 Perusahaan PLTGU POMU Priuk Tahun 2015-2019

\begin{tabular}{cccc}
\hline Tahun & $\begin{array}{c}\text { Hasil } \\
\text { penilaian } \\
(\boldsymbol{\%})\end{array}$ & $\begin{array}{c}\text { Sifat audit } \\
\text { internal } \\
\text { /eksternal }\end{array}$ & $\begin{array}{c}\text { Ketera- } \\
\text { ngan } \\
(\boldsymbol{\%})\end{array}$ \\
\hline 2015 & 92,00 & Eksternal & - \\
2016 & 91,69 & Internal & $-0,31$ \\
2017 & 91,07 & Internal & $-0,62$ \\
2018 & 91,56 & Eksternal & 0,49 \\
2019 & 90,78 & Internal & $-0,78$ \\
\hline
\end{tabular}

Data diolah (2020)

Tabel 1 menggambarkan bahwa hasil penilaian audit SMK3 di Perusahaan PLTGU POMU Priuk untuk tahun 2015 sebesar 92,00\%, tahun 2016 sebesar $91,69 \%$, tahun 2017 sebesar $91,07 \%$, tahun 2018 sebesar 91,562\%, tahun 2019 sebesar $90,78 \%$, sehingga kinerja SMK3 dari tahun 2015-2019 cenderung fluktuatif, jika diaudit oleh internal dan atau eksternal. Hal tersebut diduga disebabkan oleh berbagai faktor seperti dukungan manajemen, partisipasi pekerja, dan salah satunya adalah kompetensi ahli K3 dan atau kinerja. Penelitian Ardi dan Hariyono [3] dan Kartikasari dan Sukwika [4] menyatakan bahwa keberadaan peraturan dan prosedur keselamatan dan kesehatan kerja dalam upaya mencegah penyakit akibat kerja, dan kecelakaan kerja mendorong karyawan mentaati dan mematuhi pentingnya pelaksanaan keselamatan dan kesehatan kerja. Penelitian ini bertujuan untuk menganalisa kompetensi ahli K3 terhadap kinerja SMK3 pada perusahaan PLTGU POMU Priuk.

\section{METODE PENELITIAN}

Metode yang digunakan adalah metode survei, pengumpulan data menggunakan hasil jawaban kuesioner dari responden sampel. Populasi yang digunakan adalah para pekerja di Perusahaan PLTGU POMU Priuk. Data pekerja di perusahaan PLTGU POMU Priuk ditunjukkan pada Tabel 2.
Tabel 2. Data Pegawai (Tenaga Kerja) Perusahaan PLTGU POMU Priuk

\begin{tabular}{llccc}
\hline \multirow{2}{*}{ No Bagian } & \multirow{2}{*}{ Jumlah } & \multicolumn{2}{c}{ Responden } \\
& Orang & \% \\
\hline 1 & Karyawan O & 328 & 65 & 48,2 \\
& $\&$ M & & & \\
2 & Support & 50 & 10 & 7,4 \\
3 & Tenaga bantu & 241 & 48 & 35,56 \\
4 & Keamanan & 68 & 12 & 8,5 \\
& & $\mathbf{6 8 7}$ & $\mathbf{1 3 5}$ & $\mathbf{1 0 0 \%}$ \\
\hline
\end{tabular}

\section{Sampel Penelitian}

Teknik pengambilan sampel dalam penelitian ini menggunakan purposive sampling yaitu sampel yang dipilih dari suatu populasi dengan menggunakan kriteria atau pertimbangan tertentu [5]. Sampel yang digunakan pada penelitian ini adalah berjumlah 135 orang pegawai yang bekerja di Perusahaan PLTGU POMU Priuk di Jl RE Martadinata Jakarta Utara. Data yang dihimpun meliputi persepsi (pandangan) terhadap Ahli K3 mengenai kompetensi (sikap, pengetahuan, kemampuan) terhadap kinerja SMK3 dalam bentuk pernyataan-pernyataan di dalam kuesioner.

\section{HASIL DAN PEMBAHASAN}

Hasil kuisioner diketahui sebaran data dari perolehan variabel sikap terlihat pada daftar distribusi frekuensi jawaban dalam distribusi frekuensi skor di Tabel 3. Pada tabel terlihat hasil skor dari 6 pernyataan diperoleh rata-rata sebesar 4537/135/6 = 4,37 sehingga termasuk dalam kisaran nilai rata-rata 4,21-5,00. Ini berarti bahwa sikap yang sudah dijalankan oleh Ahli K3 di Perusahaan PLTGU POMU Priuk sangat baik. Hal ini dapat dilihat dari tanggapan responden yang mayoritas menjawab "sangat setuju". Dengan demikian dapat menjelaskan bahwa sikap yang dimiliki oleh Ahli K3 menurut 135 responden pegawai yang bekerja di Perusahaan PLTGU POMU Priuk sudah sangat baik. Sehingga dengan kompetensi yang sudah sangat baik tersebut dapat juga 
meningkatkan kinerja SMK3 di Perusahaan PLTGU POMU Priuk.

Hasil data variabel pengetahuan yang diperoleh melalui kuesioner disajikan pada Tabel 4. Pada table tersebut terlihat hasil skor dari 13 pernyataan diperoleh rata-rata sebesar $7444 / 135 / 13=4,24$ sehingga termasuk dalam kisaran nilai rata-rata 4,215,00 . Ini berarti bahwa pengetahuan yang dimiliki oleh Ahli K3 yang sangat baik. Hal tersebut terdilihat dari tanggapan responden yang mayoritas menjawab "sangat setuju", dengan demikian bahwa pengetahuan yang dimiliki oleh Ahli K3 menurut 135 responden pegawai yang bekerja di Perusahaan PLTGU POMU Priuk sudah sangat baik. Yang berarti bahwa pengetahuan yang dimiliki Ahli K3 mampu membuktikan kompetensinya berfungsi dengan sangat baik, sehingga dengan kompetensi yang sudah sangat baik dalam rangka meningkatkan kinerja SMK3 di Perusahaan PLTGU POMU Priuk.

Sebaran data variabel kemampuan terlihat pada daftar distribusi frekuensi jawaban responden pada Tabel 5. Skor dari 13 pernyataan diperoleh rata-rata sebesar $7400 / 135 / 13=4,22$ sehingga termasuk dalam kisaran nilai rata-rata 4,21- 5,00. Ini berarti bahwa kemampuan yang dimiliki oleh Ahli K3 yang sangat baik. Ini tampak dari tanggapan responden yang mayoritas menjawab "sangat setuju". Ini menjelaskan bahwa kemampuan yang dimiliki oleh Ahli K3 menurut 135 responden pegawai yang bekerja di perusahaan PLTGU POMU Priuk sangat baik.

Artinya, kemampuan yang dimiliki Ahli K3 membuktikan bahwa kompetensi Ahli K3 berfungsi baik dalam rangka meningkatkan kinerja SMK3. Sebaran data variabel kinerja SMK3 sesuai distribusi frekuensi jawaban responden disajikan pada Tabel 6. Hasil skor dari 13 pernyataan diperoleh rata-rata sebesar 7318/135/13= 4,17 atau masuk dalam kisaran nilai 3,414,20. Kinerja SMK3 yang dimiliki oleh Ahli K3 tergolong baik. Ini didasarkan tanggapan "setuju" dari mayoritas responden. Artinya, kinerja SMK3 berfungsi dengan baik yang dibuktikan oleh kepemilikan kompetensi Ahli K3. Ini membuktikan bahwa kinerja SMK3 di perusahaan PLTGU POMU Priuk dipengaruhi oleh kompetensi Ahli K3 dalam hal ini adalah (sikap, pengetahuan dan kemampuan).

Tabel 3. Distribusi Frekuensi Tanggapan Responden Pada variabel Sikap

\begin{tabular}{|c|c|c|c|c|c|c|}
\hline \multicolumn{7}{|c|}{ Sikap } \\
\hline \multirow{3}{*}{ Sikap } & & & & Skor & & \multirow{3}{*}{ Total } \\
\hline & STS & TS & $\mathbf{N}$ & $\mathbf{S}$ & SS & \\
\hline & 1 & 2 & 3 & 4 & 5 & \\
\hline S1 & & 2 & 10 & 74 & 49 & 135 \\
\hline $\mathrm{S} 2$ & & 1 & 4 & 64 & 66 & 135 \\
\hline S3 & & 2 & 7 & 72 & 54 & 135 \\
\hline S4 & & 4 & 6 & 66 & 59 & 135 \\
\hline S5 & & 2 & 2 & 65 & 66 & 135 \\
\hline S6 & & 2 & 2 & 71 & 60 & 135 \\
\hline Frekuensi Skor Indo 1 (f1) & 0 & 13 & 31 & 412 & 354 & 810 \\
\hline Jumlah Skor (f1 x skor) & 0 & 26 & 93 & 1648 & 1770 & 3537 \\
\hline Jumlah Skor Ideal (f1 x 5) & 0 & 65 & 155 & 2060 & 1770 & 4050 \\
\hline Persentase Skor Ind.1 & $0,00 \%$ & $1,60 \%$ & $3,83 \%$ & $50,86 \%$ & $43,70 \%$ & $100,00 \%$ \\
\hline \multicolumn{6}{|c|}{ Jumlah skor/ Jumlah sampel/6 pernyataan } & 4,37 \\
\hline
\end{tabular}

Sumber: Data diolah (2020) 
Tabel 4. Distribusi Frekuensi Variabel Pengetahuan

\begin{tabular}{|c|c|c|c|c|c|c|}
\hline \multicolumn{7}{|c|}{ Pengetahuan } \\
\hline Pengetahuan & $\begin{array}{c}\text { STS } \\
1\end{array}$ & $\begin{array}{c}\text { TS } \\
2\end{array}$ & $\begin{array}{l}\mathbf{N} \\
\mathbf{3}\end{array}$ & $\begin{array}{r}S \\
4 \\
\end{array}$ & $\begin{array}{c}\text { SS } \\
5\end{array}$ & Total \\
\hline P1 & - & - & 4 & 86 & 45 & 135 \\
\hline $\mathrm{P} 2$ & - & - & 12 & 75 & 48 & 135 \\
\hline P3 & - & - & 3 & 72 & 60 & 135 \\
\hline P4 & - & - & 5 & 79 & 51 & 135 \\
\hline P5 & - & 1 & 7 & 89 & 38 & 135 \\
\hline P6 & - & 1 & 8 & 90 & 36 & 135 \\
\hline P7 & - & - & 11 & 82 & 42 & 135 \\
\hline P8 & & 1 & 15 & 85 & 34 & 135 \\
\hline P9 & - & - & 10 & 84 & 41 & 135 \\
\hline P10 & - & - & 15 & 86 & 34 & 135 \\
\hline P11 & - & - & 5 & 87 & 43 & 135 \\
\hline P12 & - & - & 10 & 86 & 39 & 135 \\
\hline P13 & - & - & 9 & 93 & 33 & 135 \\
\hline Frekuensi Skor Indo 1 (f1) & 0 & 3 & 114 & 1094 & 544 & 1755 \\
\hline Jumlah Skor (f1 x skor) & 0 & 6 & 342 & 4376 & 2720 & 7444 \\
\hline Jumlah Skor Ideal (f1 x 5) & 0 & 15 & 570 & 5470 & 2720 & 8775 \\
\hline Persentase Skor Ind.1 & $0,00 \%$ & $0,17 \%$ & $6,50 \%$ & $62,34 \%$ & $31,00 \%$ & $100,00 \%$ \\
\hline \multicolumn{6}{|c|}{ Jumlah skor/ Jumlah sampel/13 pernyataan } & 4,24 \\
\hline
\end{tabular}

Tabel 5. Distribusi Frekuensi Variabel Kemampuan

\begin{tabular}{|c|c|c|c|c|c|c|}
\hline \multicolumn{7}{|c|}{ Kemampuan } \\
\hline \multirow[b]{2}{*}{ Kemampuan } & & & & Skor & & \multirow[b]{2}{*}{ Total } \\
\hline & $\begin{array}{c}\text { STS } \\
1\end{array}$ & $\begin{array}{c}\text { TS } \\
2\end{array}$ & $\begin{array}{l}\mathbf{N} \\
\mathbf{3}\end{array}$ & $\begin{array}{l}S \\
4\end{array}$ & $\begin{array}{c}\text { SS } \\
5\end{array}$ & \\
\hline K1 & - & 1 & 13 & 88 & 33 & 135 \\
\hline K2 & - & 2 & 11 & 81 & 41 & 135 \\
\hline K3 & - & - & 4 & 95 & 36 & 135 \\
\hline K4 & - & - & 4 & 83 & 48 & 135 \\
\hline K5 & - & - & 10 & 83 & 42 & 135 \\
\hline K6 & - & 1 & 8 & 87 & 39 & 135 \\
\hline K7 & - & 2 & 8 & 84 & 41 & 135 \\
\hline K8 & - & 2 & 9 & 81 & 43 & 135 \\
\hline K9 & - & 1 & 15 & 84 & 35 & 135 \\
\hline K10 & - & - & 8 & 91 & 36 & 135 \\
\hline K11 & - & - & 14 & 81 & 40 & 135 \\
\hline K12 & - & - & 10 & 87 & 38 & 135 \\
\hline K13 & - & 1 & 4 & 84 & 46 & 135 \\
\hline Frekuensi Skor Indo 1 (f1) & 0 & 10 & 118 & 1109 & 518 & 1755 \\
\hline Jumlah Skor (f1 x skor) & 0 & 20 & 354 & 4436 & 2590 & 7400 \\
\hline Jumlah Skor Ideal (f1 x 5) & 0 & 50 & 590 & 5545 & 2590 & 8775 \\
\hline Persentase Skor Ind.1 & $0,00 \%$ & $0,57 \%$ & $6,72 \%$ & $63,19 \%$ & $29,52 \%$ & $100,00 \%$ \\
\hline \multicolumn{6}{|c|}{ Jumlah skor/ Jumlah sampel/13 pernyataan } & 4,22 \\
\hline
\end{tabular}


Tabel 6. Distribusi Frekuensi Variabel Kinerja SMK3

\begin{tabular}{|c|c|c|c|c|c|c|}
\hline \multicolumn{7}{|c|}{ Kinerja SMK3 } \\
\hline \multirow{3}{*}{ Kinerja SMK3 } & \multicolumn{5}{|c|}{ Skor } & \multirow{3}{*}{ Total } \\
\hline & STS & TS & $\mathbf{N}$ & $\mathbf{S}$ & SS & \\
\hline & 1 & 2 & 3 & 4 & 5 & \\
\hline KS1 & - & 1 & 10 & 96 & 28 & 135 \\
\hline KS2 & - & - & 5 & 95 & 35 & 135 \\
\hline KS3 & - & - & 5 & 99 & 31 & 135 \\
\hline KS4 & - & - & 9 & 90 & 36 & 135 \\
\hline KS5 & 2 & 3 & 11 & 87 & 32 & 135 \\
\hline KS6 & 3 & 2 & 18 & 72 & 40 & 135 \\
\hline KS7 & - & - & 13 & 79 & 43 & 135 \\
\hline KS8 & - & - & 12 & 86 & 37 & 135 \\
\hline KS9 & - & - & 5 & 92 & 38 & 135 \\
\hline KS10 & - & - & 4 & 103 & 28 & 135 \\
\hline KS11 & - & - & 9 & 93 & 33 & 135 \\
\hline KS12 & - & - & 9 & 90 & 36 & 135 \\
\hline KS13 & - & 1 & 10 & 94 & 30 & 135 \\
\hline Frekuensi Skor Indo 1 (f1) & 5 & 7 & 120 & 1176 & 447 & 1755 \\
\hline Jumlah Skor (f1 x skor) & 5 & 14 & 360 & 4704 & 2235 & 7318 \\
\hline Jumlah Skor Ideal (f1 x 5) & 25 & 35 & 600 & 5880 & 2235 & 8775 \\
\hline Persentase Skor Ind.1 & $0,28 \%$ & $0,40 \%$ & $6,84 \%$ & $67,01 \%$ & $25,47 \%$ & $100,00 \%$ \\
\hline \multicolumn{6}{|c|}{ Jumlah skor/ Jumlah sampel/13 pernyataan } & 4,17 \\
\hline
\end{tabular}

\section{Uji Asumsi Klasik}

\section{Uji Normalitas}

Hasil uji normalitas diketahui Asymp Sig (2-tailed) sebesar 0,097, atau lebih besar dari 0,05 artinya data terdistribusi normal, sehingga datanya dapat dilanjutkan pada uji multikolinearitas. Selanjutnya, berdasarkan hasil uji multikolinearitas diketahui bahwa tolerance variabel sikap sebesar 0,448 dan VIF 2,233, tolerance variabel pengetahuan sebesar 0,231 dan VIF 4,330, dan tolerance variabel kemampuan sebesar 0,240 dan VIF 4,164. Perolehan angka tolerance lebih besar dari pada 0,10 (nilai VIF < dari 10), maka data yang dipakai pada penelitian ini tidak terjadi penyimpangan data.

\section{Uji Heteroskedastisitas}

Uji heteroskedastisitas untuk menguji model regresi terjadi ketidaksamaan variance dari residual satu pengamatan ke pengamatan yang lain [6]. Berdasarkan Gambar 1, tidak tampak adanya pola yang jelas pada titik-titik yang menyebar dibawah atau diatas angka 0 di sumbu $\mathrm{Y}$, sehingga disimpulkan tidak terjadi heteroskedas-tisitas.

\section{Uji Regresi Berganda}

Hasil uji regresi berganda seperti pada Tabel 7 bahwa regresi berganda mempunyai garis persamaan $\hat{Y}=12,383$ $0,094 X 1+0,276 X 2+0,519 X 3$. Artinya $: a$ $($ konstanta $)=12,383$ menyatakan bahwa jika sikap, pengetahuan dan kemampuan bernilai 0, maka kinerja SMK3 bernilai 12,383. b1 (koefisien regresi) $=-0,094$ menyatakan bahwa jika sikap bernilai 1, maka akan menurunkan kinerja SMK3 sebesar 0,0942. Artinya, variabel sikap tidak akan mampu meningkatkan kinerja SMK3, dikarenakan nilai dari sikap negatif, sehingga sikap berpotensi menurunkan kinerja SMK3. b2 (koefisien regresi) = 0,276 menyatakan bahwa jika pengetahuan 
bernilai 1, maka akan meningkatkan kinerja SMK3 sebesar 0,276. Artinya, variabel pengetahuan mampu meningkatkan kinerja SMK3, dikarenakan dari hasil perolehan pengetahuan positif. b3 (koefisien regresi) $=0,519$ menyatakan bahwa jika kemampuan bernilai 1, maka akan meningkatkan kinerja SMK3 sebesar 0,519. Artinya pada penelitian ini variabel kemampuan mampu menunjukan peningkatan kinerja SMK3, dikarenakan dari hasil perolehan kemampuan positif.
Uji koefisien determinasi berganda diketahui bahwa bahwa kontribusi sikap, pengetahuan dan kemampuan dalam meningkatkan kinerja SMK3 sebesar $66,2 \%$, sehingga $66,2 \%$ sudah cukup besar dalam mempengaruhi kinerja SMK3, dikarenakan pada umumnya masih banyak variabel-variabel atau faktor-faktor lain yang tidak masuk dalam penelitian ini seperti kepuasan kerja, faktor personal, faktor eksternal, kompensasi dan lainnya.

\section{Koefisien Determinsi Berganda}

Tabel 7. Regresi Berganda

\begin{tabular}{|c|c|c|c|c|c|}
\hline No & Variabel & B & Sig & $\begin{array}{l}\text { Persamaan pengaruh } \\
\text { (Positif atau Negatif) }\end{array}$ & Keterangan \\
\hline 1 & $\begin{array}{l}\text { Kinerja SMK3 } \\
\text { (Konstanta) }\end{array}$ & 12,383 & 0,000 & $\begin{array}{l}\text { Kinerja (konstanta) memiliki } \\
\text { nilai sebesar } 12.383\end{array}$ & \\
\hline 2 & Sikap & $-0,094$ & 0,492 & $\begin{array}{l}\text { Sikap memiliki nilai persamaan } \\
\text { pengaruh sebesar }-0,094 \text { (negatif) }\end{array}$ & $\begin{array}{l}\text { Pengaruh } \\
\text { Negatif }\end{array}$ \\
\hline 3 & Pengetahuan & 0,276 & 0,006 & $\begin{array}{l}\text { Pengetahuan memiliki nilai } \\
\text { persamaan pengaruh sebesar } \\
0,276 \text { (positif) }\end{array}$ & $\begin{array}{l}\text { Pengaruh } \\
\text { Positif }\end{array}$ \\
\hline 4 & Kemampuan & 0,519 & 0,000 & $\begin{array}{l}\text { Kemampuan memiliki nilai } \\
\text { persamaan pengaruh sebesar } \\
0,519 \text { (positif) }\end{array}$ & $\begin{array}{l}\text { Pengaruh } \\
\text { Positif }\end{array}$ \\
\hline
\end{tabular}

Sumber: Data diolah (2020)

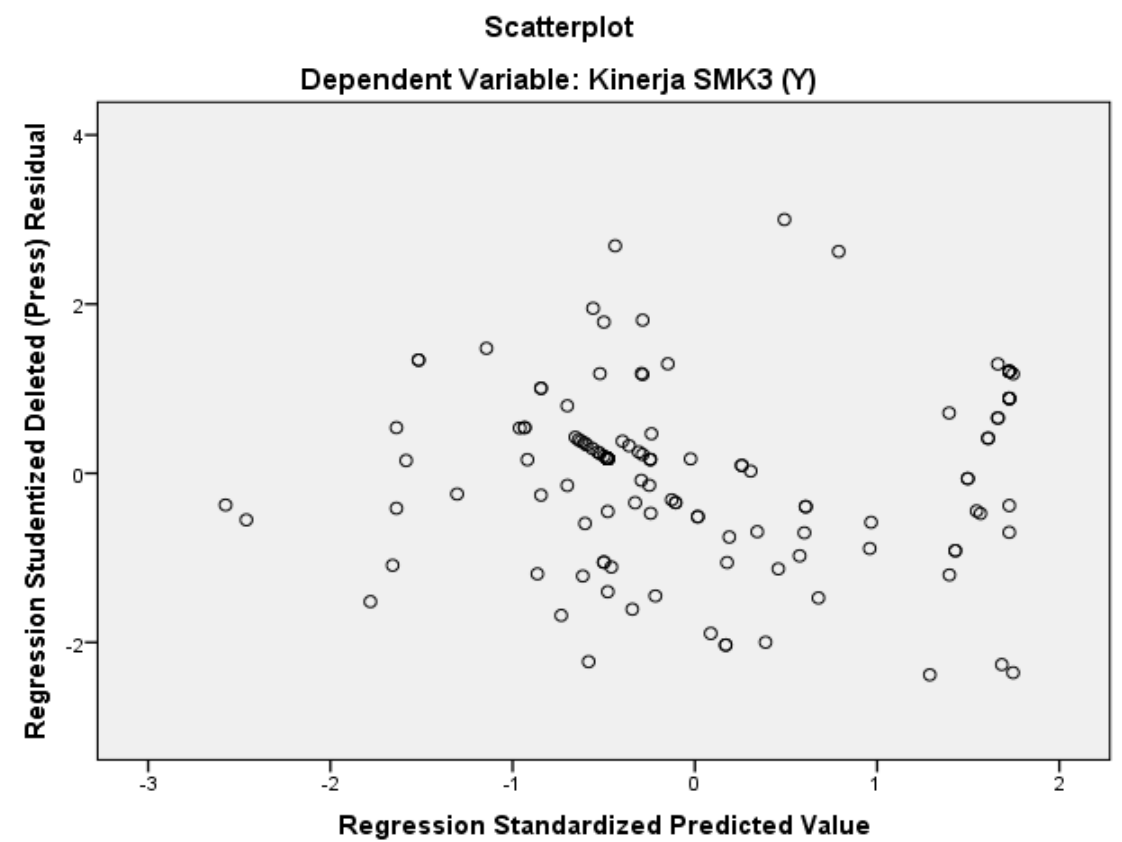

Uji Hipotesis

Gambar 1. Uji Heteroskedastisitas Uji hipotesis parsial (uji-t) 
Berdasarkan perhitungan pengujian hipotesis nilainya sig sebesar 0,492 , dengan ketentuan perolehan $\alpha=0,05$, maka nilai 0,492 lebih besar 0,05 jadi hipotesis ditolak dengan arti secara parsial variabel sikap tidak signifikan berpengaruh terhadap kinerja SMK3 pada perusahaan PLTGU POMU Priuk. Dengan kata lain, secara parsial bahwa sikap yang dijalankan oleh Ahli K3 tidak terbukti mampu mempengaruhi kinerja SMK3. Hal ini dikarenakan sikap kerja seorang Ahli K3 menurut persepsi para pekerja di perusahaan PLTGU POMU Priuk tidak mempengaruhi hasil secara langsung karena Ahli K3 tersebut tidak langsung mengerjakannya, sehingga tidak terbukti bahwa sikap dapat meningkatkan kinerja SMK3.

Nilai sig sebesar 0,006 , artinya secara parsial pengetahuan mempengaruhi kinerja SMK3 di Perusahaan PLTGU POMU Priuk. Selanjutnya perolehan nilai sig sebesar 0,000, adapun ketentuan perolehan $\alpha=0,05$ artinya nilai 0,006 lebih kecil 0,05 , hingga hipotesis diterima. Berarti bahwa secara parsial variabel kemampuan mempengaruhi kinerja SMK3 pada Perusahaan PLTGU POMU Priuk.

\section{Uji hipotesis berganda (Uji-F)}

Perolehan hipotesis nilai sig sebesar 0,000 menyatakan bahwa sikap, pengetahuan dan kemampuan dapat meningkatkan kinerja SMK3 pada perusahaan PLTGU POMU Priuk. Dengan kata lain, secara berganda bahwa kinerja SMK3 terbukti dapat dipengaruhi sikap, pengetahuan dan kemampuan yang dimiliki Ahli K3. Artinya, sikap perlu didukung pula oleh pengetahuan dan kemampuan untuk seorang Ahli K3, maka kompetensi yang diharapkan dapat terwujud dan dengan kompetensi yang lengkap yang terdiri dari sikap, pengetahuan dan kemampuan perlu diimplementasikan secara bersamaan sehingga kinerja setiap pekerja meningkat.

\section{Pembahasan}

\section{Sikap pada Kinerja SMK3}

Hasil hipotesis diperoleh nilai sig sebesar 0,492, artinya nilai 0,492 lebih besar 0,05, Berarti bahwa secara individu bahwa sikap yang dimiliki Ahli K3 belum mampu meningkatkan kinerja SMK3. Hal ini dikarenakan kompetensi pada sikap Ahli K3 dihasilkan melalui persepsi para pekerja di perusahaan PLTGU POMU Priuk, sehingga tidak terbukti bahwa sikap dapat meningkatkan kinerja SMK3.

Hasil penelitian ini menunjukkan kesamaan dengan penelitian lainnya yaitu kajian yang dilakukan oleh Astuti dan Nurtjahjanti [7] disebutkan bahwa sikap dapat meningkatkan keselamatan kerja pada perusahaan PLN, dari perspektif lain dinyatakan oleh Manurung dan Sukwika [8] bahwa sikap pun dapat menekan kejadian tingkat kecelakaan.

\section{Pengetahuan pada Kinerja SMK3}

Pengujian hipotesis diperoleh angka sig nya 0,000 , secara parsial pengetahuan berpengaruh meningkatkan kinerja SMK3. Dengan kata lain, jika pengetahuan yang dimiliki oleh Ahli K3 baik, maka kinerja SMK3 semakin meningkat. Artinya, secara individu pengetahuan yang dimiliki oleh Ahli K3 mampu meningkatkan kinerja SMK3. Untuk seorang Ahli K3 ilmu pengetahuan harus lebih baik, karena fungsi dan tugas seorang Ahli K3 sebagai supervisi dan pengawasan pekerjaan dalam mencapai Kinerja SMK3.

Kondisi di atas sejalan dengan penelitian Hartono dan Sutopo [9] bahwa pengetahuan meningkatkan persepsi penerapan keselamatan dan kesehatan kerja dalam menjalanakan aktivitas kinerja. Selanjutnya penelitian lainnya Rahayu [10] bahwa pengetahuan memiliki hubungan 
dengan penerapan manajemen budaya keselamatan dan kesehatan kerja, bahkan menurut Purba dan Sukwika [11] bahwa pengetahuan K3 dapat meningkatkan produktivitas kerja.

\section{Kemampuan pada Kinerja SMK3}

Pengujian hipotesis diperoleh angka sig sebesar 0,000, yang berarti secara individu variabel kemampuan signifikan berpengaruh terhadap kinerja SMK3. Indikasinya, jika kemampuan yang dimiliki oleh Ahli K3 baik, maka kinerja SMK3 semakin baik pula. Artinya, secara individu kemampuan yang dimiliki Ahli K3 bisa menunjukkan performa kinerja SMK3 yang baik. Adanya tuntuntan bahwa kemampuan Ahli K3 harus lebih baik karena fungsi dan tugas seorang Ahli K3 itu sebagai supervisi dan pengawasan pekerjaan dalam mencapai Kinerja SMK3.

Hal ini sejalan dengan penelitian Soetrisno dan Gilang [12] bahwa kompetensi meningkatkan kinerja karyawan pada perusahaan telekomunikasi. Kemudian dipertegas oleh Putra, et al. [13] bahwa kemampuan kerja mampu dapat meningkatkan kinerja pegawai di kota Semarang, dan situasi serupa ditemukan juga oleh Agustina dan Sukwika [14] terkait kapasitas pegawai dengan kinerja pegawai pada direktorat sumber daya kemedikbud.

\section{Sikap, Pengetahuan dan Kemampuan pada Kinerja SMK3}

Pengujian hipotesis diperoleh angka sig-nya 0,000 , bahwa sikap, pengetahuan serta kemampuan signifikan berpengaruh terhadap kinerja SMK3, diterima. Dengan kata lain, bahwa kinerja SMK3 terbukti dapat dipengaruhi sikap, pengetahuan dan kemampuan. Berarti secara simultan/ berganda bahwa sikap dan pengetahuan serta kemampuan yang dimiliki Ahli K3 mampu meningkatkan kinerja SMK3. Hal tersebut dikarenakan kompetensi yang baik yaitu kompetensi yang terdiri dari pengetahuan dan kemampuan serta sikap kerja yang cukup, karena fungsi dan tugas seorang Ahli K3 itu adalah sebagai supervisi dan pengawasan pekerjaan dalam mencapai Kinerja SMK3, sehingga dalam menjalankan aktivitasnya harus memiliki kompetensi yang memadai.

Hal tersebut sejalan dengan penelitian Sutrisno [15] dan Purba dan Sukwika [11] bahwa baiknya kompetensi para pekerja dapat meminimalisir risiko terjadinya kecelakaan kerja. Begitu juga penelitian Bayram [16] menyimpulkan bahwa kompetensi dapat meningkatkan kinerja keselamatan, pada perusahaan manufaktur. Sementara Manurung dan Sukwika [8] menekankan perlunya komitmen dan sikap dalam menekan kejadian kecelakaan di lingkungan kerja.

\section{KESIMPULAN}

Secara parsial, variabel sikap tidak terbukti berpengaruh signifikan terhadap kinerja SMK3, artinya sikap yang dijalankan oleh Ahli K3 tidak terbukti mampu mempengaruhi kinerja SMK3. Adapun variabel pengetahuan dan kemampuan terbukti berpengaruh signifikan terhadap kinerja SMK3, artinya pengetahuan dan kemampuan yang dimiliki oleh Ahli K3 baik, maka kinerja SMK3 semakin baik. Secara simultan variabel sikap, pengetahuan dan kemampuan terbukti berpengaruh terhadap kinerja SMK3, yang berarti secara simultan kinerja SMK3 terbukti dapat dipengaruhi oleh sikap, pengetahuan dan kemampuan ahli K3.

Implikasi manajerial yaitu perlu adanya sikap yang baik yang disertai pengetahuan dan keampuan yang cukup untuk menghasilkan kinerja yang baik. Pada lingkungan perusahaan perlu peningkatan kompetensi yang didasarkan pada kinerja. 
Perbaikan terhadap sikap atau perilaku dapat dilakukan dengan pengawasan dalam melaksanakan SMK3. Pemberian pemahaman tentang pentingnya pengetahuan dapat ditempuh melalui

\section{DAFTAR PUSTAKA}

[1] T. K. Noviastuti, E. Ekawati, and B. Kurniawan, "Analisis upaya penerapan manajemen K3 dalam mencegah kecelakaan kerja di proyek pembangunan fasilitas penunjang bandara oleh PT. x (studi kasus di proyek pembangunan bandara di Jawa Tengah)," Jurnal Kesehatan Masyarakat (e-Journal), vol. 6, no. 5, pp. 648-653, 2018.

[2] O. E. Lumempow, A. K. Dundu, and T. T. Arsjad, "Study penerapan standar kompetensi kerja nasional Indonesia (SKKNI) bidang K3 (Studi kasus: Pembangunan gedung laboratorium fakultas teknik unsrat)," Jurnal Sipil Statik, vol. 6, no. 12, pp. 1085-1094, 2018.

[3] S. Z. Ardi, and W. Hariyono, "Analisa penerapan budaya perilaku keselamatan dan kesehatan kerja di rumah sakit," Jurnal Fakultas Kesehatan Masyarakat, vol. 12, no. 1, pp. 15-20, 2018.

[4] S. E. Kartikasari, and T. Sukwika, "Disiplin K3 melalui pemakaian alat pelindung diri (APD) di laboratorium kimia PT Sucofindo," VISIKES: Jurnal Kesehatan Masyarakat, vol. 20, no. 1, pp. 41-50, 2021.

[5] I. Imron, "Analisa pengaruh kualitas produk terhadap kepuasan konsumen menggunakan metode kuantitatif pada CV. meubele berkah Tangerang," Indonesian Journal on Software pelatihan on job training atau praktek kerja lapangan, sedangkan untuk sikap melalui praktik kedisiplin dan kepatuhan agar lebih baik kinerja di perusahaan tersebut.

Engineering (IJSE), vol. 5, no. 1, pp. 19-28, 2019.

[6] I. Ghozali, Aplikasi analisis multivariat dengan program IBM SPSS 23 (VIII), Semarang: Badan Penerbit Universitas Diponegoro, 2016.

[7] I. M. Astuti, and H. Nurtjahjanti, "Hubungan antara sikap terhadap keselamatan kerja dengan komitmen organisasi pada pegawai PT. PLN (PERSERO) area pelaksana pemeliharaan Semarang," Empati, vol. 6, no. 4, pp. 439-443, 2018.

[8] L. A. Manurung, and T. Sukwika, "Penerapan kartu stop program sebagai faktor penekan kejadian kecelakaan kerja," Journal of Applied Management Research, vol. 1, no. 1, pp. 1-10, 2021.

[9] A. Hartono, and S. Sutopo, "Pengaruh pengetahuan, sikap dan kondisi lingkungan kerja terhadap persepsi penerapan keselamatan dan kesehatan kerja," Jurnal Dinamika Vokasional Teknik Mesin, vol. 3, no. 2, pp. 76-81, 2018.

[10] E. P. Rahayu, "Hubungan antara pengetahuan, sikap, dan perilaku karyawan dengan penerapan manajemen budaya keselamatan dan kesehatan kerja," Jurnal Kesehatan Komunitas, vol. 2, no. 6, pp. 289-293, 2015.

[11] S. U. Purba, and T. Sukwika, "Pengaruh program keselamatan dan kesehatan kerja terhadap 
produktivitas kerja pada divisi proyek," Journal of Applied Management Research, vol. 1, no. 1, pp. 67-77, 2021.

[12] A. P. Soetrisno, and A. Gilang, "Pengaruh kompetensi terhadap kinerja karyawan (Studi di PT. telekomunikasi Indonesia Tbk witel Bandung)," 8, vol. 1, no. 61-76, 2018.

[13] D. C. Putra, M. Mustam, and T. Yuniningsih, "Pengaruh kemampuan kerja dan lingkungan kerja terhadap kinerja pegawai di kecamatan gayamsari kota semarang," Journal of Public Policy and Management Review, vol. 2, no. 4, pp. 194-203, 2013.

[14] S. S. Agustina, and T. Sukwika, "Analisis kinerja pegawai pada direktorat sumber daya, ditjen dikti kemendikbud," Journal of Applied Management Research, vol. 1, no. 1, pp. 34-44, 2021.

[15] A. Sutrisno, "Analisis efektifitas implementasi program keselamatan dan kesehatan kerja (K3) pada proyek konstruksi (Studi kasus: Proyek pabrik textil pt indorama jatiluhur Purwakarta)," Jurnal Techno Sosio Ekonomika, vol. Edisi Khusus, no. 01, pp. 80-96, 2019.

[16] M. Bayram, "Safety training and competence, employee participation and involvement, employee satisfaction, and safety performance: An empirical study on occupational health and safety management system implementing manufacturing firms," Alphanumeric Journal, vol. 7, no. 2, pp. 301-318, 2019. 